\title{
STUDYING LANGUAGE AND CULTURE THROUGH PARTICIPATION IN LONG-TERM EXCHANGE PROGRAMS
}

\author{
A.P. Ostrovskiy, P.J. Mitchell
}

\begin{abstract}
The article is dedicated to long-term exchange programs. They are examined as a means of studying foreign languages and exploring the culture of the host country, along with the many aspects of the culture and how these aspects influence students. The benefits of such programs are reviewed.

Keywords: international exchange program, culture, immersion, stereotype.
\end{abstract}

\section{Introduction}

International exchange programs are programs organized by foreign institutions along with public authorities that let students from different countries live and study abroad [1]. The market of international exchange programs is relatively young, with the first programs being arranged in the 1990s but the proper formation of such programs was completed at the beginning of the 2000s.

\section{Studying a culture}

For the achievement of the goals in language learning, a specific type of exchange programs is required. Programs should provide an opportunity to live in a host family and study in a common school, college or university depending on the age of the student; they can be both public and private. As it is important for high school students to live in a host family, it is no less important for college students to live in a dormitory with other students. In such conditions, an environment conducive to students' language learning is established. The students experience the greatest influence of language and culture, which is necessary for the main goal of such programs - cultural exchange (studying a culture) with possible strengthening of economic and political contacts [2]. Only in such a case will full immersion in a new environment and culture be possible. Another important aspect is the interpersonal contacts that play a big role in the programs. By virtue of interpersonal contacts views of two nations change about each other. This process has been actively developing since the 1990s between Russia and the USA [3]. An international student appears to be in a spectacular situation; all the people that surround the student are strangers. It is logical to think that such a situation may occur not only abroad but also in a student's native country when a high school student graduates from school and enters an institution 
of higher education, but actually it is not absolutely like that. The reason is that becoming acquainted with the mentality, behavior and habits of compatriots occurs throughout life but it is possible only to guess about the same features of foreigners or there is a way to judge by movies, books, mass media but none of these sources is a reliable. In a similar situation, the foreign people of a host country appear to be but there is a major difference between them and an exchange student. For foreigners there is only one student that represents the whole culture and country, which makes the situation for an exchange student much harder. Some people may draw conclusions about a country that can be based only on the behavior of one exchange student. It is possible to conclude that during communication not only the student learns something new about a country and its people but also makes an impression on foreigners and allows them to learn something about their country and culture. This means that sometimes studying becomes an exchange, in this case a cultural exchange.

Students study culture not only because of communication between international students and foreigners. There will be cultural value in any interaction with a new environment for a student. The value might be unnoticeable at the first glance, the value might be small in some situations but that is not the matter, it is important to understand that the whole experience will be built from a variety of different situations. An ordinary visit to a supermarket or going out for a dinner will give a new experience, it may be both pleasant and disappointing but there is always something new to explore. Visiting any public place such as a park can give an opportunity to observe different peculiarities of people's behavior, how they communicate and interact with each other, what specific things demonstrate their belonging to their culture. An exchange student does not have to do such things on purpose, sometimes an international student explores such peculiarities without any intensity; these things may happen on their own.

Studying a culture through participation in international exchange programs and cultural exchange lead to an expansion of open views such as sociocultural tolerance [4]. Development of tolerance is a natural result of a participation in an exchange program. While a student gets acquainted with a new culture, he/she starts to overcome his/her own prejudices that could have been formed before coming to the foreign country. Negative attitude can by formed by several factors for example: family, peers, literature, mass media but for mostly everyone personal experience is always more trustable than someone else's opinion. That is why ideally someone's opinion should be confirmed by personal experience. While a student stays in a host country, he/she may change his/her opinion about the country, culture or some social groups. The majority of people have many various stereotypes, yet thinking through the prism of stereotypes makes their minds inflexible and biased; stereotypes do not let them think freely and they cannot make some 
independent thoughts about events that happen in foreign countries. Stereotypes can make false impressions about the citizens of some country, spreading of stereotypes may be the reason of a negative image of a country in the minds of other countries citizens. Breaking of stereotypical thinking is also a part of studying a culture. Exchange programs work in a specific way; they help to break stereotypes about two countries at the same time - stereotypes about a host country and about a country where an international student is from.

During a long stay in a host country a student can learn such information that will make stereotypes disappear, setting one's mind free. With such experience, a student is able to share newly-gained knowledge with his/her compatriots and make more and more people know the truth and actual situation. For the citizens of a host country an international student will be a source of the same knowledge, for example some student from Siberia can change the views of an ordinary American about the Siberian climate. Nevertheless, it is important to understand that this process is not absolute and that strengthening of stereotypes and prejudices is possible. Oddly enough, there is no tragedy in such a process, this proves that not all stereotypes are lies; some of them have logic and a strong basis. In this case, a stereotype as a simplified idea about something becomes an inappropriate term, because the idea has a specific personal experience.

\section{Studying a language}

Spending time in a country which speaks a language that a student studies is always very helpful, it has a great impact on the level of a student's knowledge, it can be considered as one of the best ways to study or to improve a language. There is one requirement of making the best progress. The requirement is that a student should have as little contact with compatriots as possible; it should be reduced to a minimum. That opportunity is provided by international exchange programs. The student is in the best conditions for studying a foreign languages or improving its level. With a native speaker conversation can change its direction in a minute, which is why such communication mobilizes all learner resources [5]. A participant of a program will not have a chance to ask for a word's translation and will not be able to use a dictionary during an ordinary talk; he/she will have to find a way to solve the problem somehow. There are variants like trying to find the synonym of a word or its explanation, anyway both variants are useful. Skills of listening comprehension will grow every day. Students get used to the pronunciation of their teacher. Non-native speaker teachers usually make an effort to speak properly but they cannot do it naturally on the level of a native speaker. A native speaker does not make efforts to pronounce sounds correctly. It does not matter how much effort a teacher makes to sound natu- 
ral there still will be an accent, students get used to it and therefore they have troubles with the comprehension of native speakers' spoken language. All the drawbacks are eliminated while a student has conversations with native speakers. Even talking with a foreigner that has a speech impediment is very useful. A student will not notice progress in pronunciation at first, because the progress is slow and gradual but when a student returns home, the results will be noticeable not only to a student but also to his/her peers. The level of grammar will grow from the first days, at the beginning because a student will put much effort into using only grammatically correct constructions in order to be understood. After some time a student will think less and less about how to speak correctly because of unstoppable practice. There will be fewer and fewer mistakes and if they appear that will be clear for a student due to the feeling for a language that improves greatly. The most noticeable improvement will be in speaking because the majority of language practice will be just simple talks. Some students may discover one impressive change while spending time in a foreign country; they start to think and to dream in a foreign language.

Besides people speaking a foreign language there will be books, movies, TV and radio programs, videogames and music in a foreign language. An activity that was enjoyable at home becomes another way of studying a foreign language. There is a variety of student books that are used to teach foreign languages but they may contain elements of a foreign language that are not used anymore or they are not a common form. Studying a language in a foreign country gives an opportunity to learn a language that people really use but not one that is from an outdated student's book.

\section{Conclusion}

It can be seen, therefore, that international exchange programs provide certain important advantages to foreign language learners, which are not available to those who study a foreign language in their native country. Cultural immersion is an essential part of international exchange programs and has many useful aspects. In the context of learning a language, participating in exchange programs allows students to make huge improvements in the level of proficiency in a foreign language.

\section{References}

1. Sazonova, N.V.: Rossiysko-Amerikanskiye programmy obmena: istoriya i sovremennost' [Russian-American exchange programs: history and present day (1958-2005)]. The Bulletin of Volgograd State University. Series 4, History. Regional Science. Foreign Relations. 12. pp.101-107. (2007). (In Russian)

2. Zhukova, L.S.: Formy sotsial'no-kul'turnoy deyatel'nosti dlya razvitiya mezhkul'turnoy kommunikatsii $\mathrm{v}$ ramkakh programmy mezhdunarodnogo studencheskogo obmena 
[Forms of socio-cultural activity for development of cross-cultural communication within the international students exchange programme]. The Bulletin of Kemerovo State University of Culture and Arts. 37 (2). pp. 184-189. (2016). (In Russian)

3. Chahc, L.A., Maryin, E. N.: Osobennosti mirovogo rynka programm obmena v perspektive [Features of world market of exchange programmes in the future] // The Bulletin of Omsk State University. Series: Ekonomics. 1. pp.11-13. (2009). (In Russian)

4. Sergeyev, S.O.: Akademicheskaya mobil'nost' kak instrument myagkoy sily nauki [Academic mobility as a tool of soft power of science]. Humanities, social-economic and social sciences. 6 (1). pp.198-201. (2015). (In Russian)

5. Shepelyeva, N.Y.: Ispol'zovaniye kommunikativnoy metodiki v prepodavanii angliyskogo yazyka (na primere mezhdunarodnoy programmy Fulbright c nositelyami yazyka) [The use of communicative method in teaching English (the example of Fulbright international programme with native speakers)]. The Bulletin of Kostroma State University. 5. pp.207208. (2014). (In Russian)

\section{Information about the authors:}

Ostrovskiy A.P. - student, Faculty of Foreign Languages, National Research Tomsk State University (Tomsk, Russia). E-mail: aleksandrostrovskiy1803@yandex.ru

Mitchell P.J. - associate professor, Department of English Philology, Faculty of Foreign Languages, National Research Tomsk State University; professor, Department of Linguistics and Humanities Education, Derzhavin Tambov State University (Tomsk, Tambov, Russia). E-mail: peter_mitchell@mail.ru 